\title{
Desire to practice postpartum contraception among antenatal women at Awka, Southeast Nigeria
}

\author{
Cyril C. Ezenyeaku*, Ifeanyichukwu U. Ezebialu' ${ }^{1}$, Joseph C. Umeobika1, \\ Lawrence C. Ikeako', Geoffrey I. Ubboe ${ }^{1}$, Chukwuemeka E. Ojiyi', \\ Tochukwu C. Okeke², Chijioke A. Ezenyeaku ${ }^{3}$
}

\begin{abstract}
${ }^{1}$ Department of Obstetrics and Gynecology, Chukwuemeka Odumegwu Ojukwu University Teaching Hospital, Awka, Nigeria

${ }^{2}$ Department of Obstetrics and Gynecology, University of Nigeria Teaching Hospital, Enugu, Nigeria

${ }^{3}$ Department of Community Medicine, Nnamdi Azikiwe University Teaching Hospital, Nnewi, Nigeria
\end{abstract}

Received: 17 February 2018

Accepted: 17 March 2018

\section{*Correspondence: \\ Dr. Cyril Chukwuma Ezenyeaku, \\ E-mail: cyrilezenyeaku@yahoo.com}

Copyright: ( $)$ the author(s), publisher and licensee Medip Academy. This is an open-access article distributed under the terms of the Creative Commons Attribution Non-Commercial License, which permits unrestricted non-commercial use, distribution, and reproduction in any medium, provided the original work is properly cited.

\begin{abstract}
Background: Postpartum contraception enables the nursing woman recover from the effects of pregnancy and childbirth before embarking on another pregnancy. It also promotes child welfare. The assessment of the desire by pregnant women to take up postpartum contraceptive service will help the planning of good delivery of this service. Methods: A cross-sectional study of antenatal clinic attendees at Chukwuemeka Odumegwu Ojukwu Teaching Hospital, Awka was done using a pretested interviewer-administered questionnaire. Data was analyzed with IBM SPSS version 20 software and associations between variables were tested with Chi square. Level of significance was set at $\mathrm{P} \leq 0.05$.

Results: A total of 262 antenatal women were interviewed. The mean age of the respondents was $29.1 \pm 6.1$ years while the mean parity was $2.5 \pm 1.5$. Two hundred and one of the study women $(76.7 \%)$ had the desire to practice postpartum contraception after the index pregnancy while only $9(3.4 \%)$ were unsure whether they had the desire or not. Multiparous women are more likely to desire postpartum contraception $(\mathrm{P}<0.01)$. Also, previous use of contraception $(\mathrm{P}<0.01)$, desired index pregnancy $(\mathrm{P}=0.01)$ and being married or single $(\mathrm{P}=0.02)$ are all significantly associated with the desire to practice postpartum contraception.

Conclusions: There was a high level of desire to practice postpartum contraception among antenatal clinic attendees at Awka. Parity, marital status, desired index pregnancy and previous practice of contraception all influence this desire.
\end{abstract}

Keywords: Antenatal women, Awka, Desire, Postpartum contraception

\section{INTRODUCTION}

The promotion of the use of postpartum contraception represents one avenue to address high mortality rates, as well as population growth in sub-Saharan Africa., ${ }^{1,2}$ Family planning promotion has improved uptake of contraception and a reduction of fertility rates in industrialized countries; the same has not, however, held true for developing nations- in sub-Saharan Africa in particular. $^{2}$ The continent continues to experience high fertility rates, despite considerable identification of the unmet needs for family planning in both rural and urban locales.

Postpartum family planning (contraception) is defined as the prevention of unintended pregnancy and closely 
spaced pregnancies through the first 12 months following childbirth. ${ }^{3,4}$ Even though some traditional Nigerian cultures maintain postpartum sexual abstinence until the child is weaned, some breastfeeding women may rely on their lactation for contraception. ${ }^{2,5}$ This is usually associated with high failure rates.

Men were generally married to several wives in the past and a woman after childbirth was obliged to stay away from the husband with the aim of offering her the opportunity to breastfeed for as long as 2-3 years without intercourse to prevent pregnancy.

This culture has substantially changed as monogamous family setting has taken root in many Nigerian traditional cultures. $^{2}$ The benefits of FP in maternal and child health have been demonstrated by several studies. ${ }^{6-9}$

Commencement of sexual intercourse postpartum may also herald a greater risk of unintended pregnancies. Indeed, sexual intercourse may commence as early as 5 weeks postpartum. ${ }^{10}$ Some women may be fecund few weeks after delivery especially those that are not breastfeeding.

Unintended pregnancy may lead to emotional and economic disquiet in the family which may culminate in seeking criminal abortion with its far-reaching consequences. ${ }^{2}$ It has been demonstrated that women could have barriers to their choices of contraception even when they are willing to use them. ${ }^{11}$

A study in Southwest Nigeria has shown that multiple antenatal contraceptive counselling is more effective than single sixth week postnatal visit counselling as is usually done. $^{12}$

Even though awareness of contraception as shown by studies in various parts of Nigeria is relatively high, the use by women is not appreciable. ${ }^{13-18}$

Various studies on issues about knowledge attitude and practice of contraception have been done both in Nigeria and beyond but none has been carried out in Awka, Southeast Nigeria on the desire of antenatal women to accept postpartum contraception. ${ }^{19-21}$

The objectives of this study were to determine the proportion of antenatal women with the desire to practice postpartum contraception and factors influencing that desire. This, it is believed will help strategize for family planning counselling during the prenatal period.

\section{METHODS}

A cross sectional study was conducted from March, 2016 to June, 2016 in the antenatal clinic of Chukwuemeka Odumegwu Ojukwu University Teaching Hospital, Awka, Anambra State, Southeast Nigeria.The facility is a state-owned teaching hospital and serves Anambra state and adjoining areas of Enugu, Delta and Imo states.

The study instrument was an interviewer-administered semi-structured questionnaire which was initially pretested among fifty antenatal women in the hospital. Following the pretest, the instrument was modified accordingly.

A minimum sample size of 216 antenatal women was calculated using the formula for estimating simple proportions. $^{22}$

$\mathrm{n}=\mathrm{Z}^{2} \alpha \mathrm{pq} / \mathrm{d}^{2}$

Where $\mathrm{n}=$ minimum sample size; $\mathrm{Z} \alpha=$ standard relative deviate at $95 \%$ confidence level $=1.96 ; p=$ prevalence of contraceptive use in a previous similar study.

Based on a prevalence of contraceptive use before pregnancy of $57.6 \%$ found in a previous study, 21 tolerable margin of error set at 0.05 and correction for non-response made, the minimum sample size was 216 for this study.

The data was collected through interview by trained obstetrics and gynaecology registrars. The women interviewed were informed of the study and verbal consent was obtained. The participation was on voluntary basis. Interview with each woman lasted for 15-20 minutes.

The questionnaire consisted of socio-demographic characteristics including age, marital status, level of education, and occupation.

Questions were asked regarding parity, whether the pregnancy was desired, awareness and previous use of contraception. Also inquired was their willingness to practice contraception postpartum.

Data analysis was done with IBM SPSS 20. Tests of association between variables were done with Chi-square statistic and the level of significance set at $p \leq 0.05$.

\section{RESULTS}

A total of 262 antenatal women were interviewed. The mean age of the respondents was $29.1 \pm 6.1$ years while the mean parity was $2.5 \pm 1.5$.

Most of these respondents were in the 25-29 years age group (36\%) and the least age group was 45 years and above $(3.2 \%)$.

Multiparous women accounted for the largest number of respondents $(37.3 \%)$ while grandmultiparity accounted for the least number $(5.2 \%)$. 
A larger number of the clients were married (88.5\%). The 'not married' group included the unmarried women, the divorced and the widowed in this study.

Most of the study women attained tertiary level of education $(55.2 \%)$. The socio-demographic characteristics are shown in Table 1.

Two hundred and one of the study women $(76.7 \%)$ had the desire to practice postpartum contraception after the index pregnancy while only 9 (3.4\%) were unsure whether they had the desire or not.

Multiparous women are more likely to desire postpartum contraception ( $\mathrm{p}<0.01)$ but there is no statistically significant difference in the desire based on age of the respondents.

There is also statistically significant difference in the desire for postpartum contraception with respect to marital status, desired index pregnancy and previous use of contraceptive as shown in Table 2.
Table 1: Socio-demographic characteristics of the respondents.

\begin{tabular}{|c|c|c|}
\hline Variable $(\mathbf{N}=\mathbf{2 5 2})$ & Frequency & Percentage \\
\hline \multicolumn{3}{|c|}{ Age $($ years $) ;$ Mean $=29.1 \pm 6.1$} \\
\hline $15-19$ & 11 & 4.4 \\
\hline $20-24$ & 38 & 15.1 \\
\hline $25-29$ & 91 & 36.1 \\
\hline $30-34$ & 70 & 27.8 \\
\hline $35-39$ & 23 & 9.1 \\
\hline $40-44$ & 11 & 4.4 \\
\hline 45 and above & 8 & 3.2 \\
\hline \multicolumn{3}{|c|}{ Parity; Mean $=2.5 \pm 1.5$} \\
\hline Para 0 & 81 & 32.1 \\
\hline Para 1 & 64 & 25.4 \\
\hline Para 2-4 & 94 & 37.3 \\
\hline Para 5 and above & 13 & 5.2 \\
\hline \multicolumn{3}{|l|}{ Marital status } \\
\hline Married & 223 & 88.5 \\
\hline Not married & 29 & 11.5 \\
\hline \multicolumn{3}{|l|}{ Educational status } \\
\hline Primary & 2 & 0.8 \\
\hline Secondary & 111 & 44 \\
\hline Tertiary & 139 & 55.2 \\
\hline
\end{tabular}

Table 2: Association between selected variables and desire to practice postpartum contraception.

\begin{tabular}{|c|c|c|c|c|c|}
\hline \multirow[t]{2}{*}{ Variable } & \multicolumn{3}{|c|}{ Desire for postpartum contraception } & \multirow[t]{2}{*}{ Chi-square } & \multirow[t]{2}{*}{ P-value } \\
\hline & Yes & No & Not sure & & \\
\hline Age & & & & 1.88 & 0.39 \\
\hline Young ( $<35$ years $)$ & 166 & 35 & 9 & & \\
\hline Elderly (>35 years) & 35 & 7 & 0 & & \\
\hline \multicolumn{4}{|l|}{ Parity } & 27.32 & $<0.01$ \\
\hline Nulliparous & 66 & 15 & 0 & & \\
\hline Primiparous & 47 & 17 & 0 & & \\
\hline Multiparous & 79 & 6 & 9 & & \\
\hline Grandmultiparous & 9 & 4 & 0 & & \\
\hline \multicolumn{4}{|l|}{ Marital status } & 8.32 & 0.02 \\
\hline Married & 172 & 42 & 9 & & \\
\hline Not married & 29 & 0 & 0 & & \\
\hline \multicolumn{4}{|l|}{ Educational status } & 5.71 & 0.22 \\
\hline Primary & 2 & 0 & 0 & & \\
\hline Secondary & 92 & 13 & 6 & & \\
\hline Tertiary & 107 & 29 & 3 & & \\
\hline \multicolumn{4}{|c|}{ Desired index pregnancy } & 8.74 & 0.01 \\
\hline Yes & 169 & 42 & 9 & & \\
\hline No & 30 & 0 & 0 & & \\
\hline \multicolumn{4}{|c|}{ Previous use of contraception } & 17.16 & $<0.01$ \\
\hline Yes & 135 & 23 & 0 & & \\
\hline No & 66 & 16 & 19 & & \\
\hline
\end{tabular}

\section{DISCUSSION}

Most of the women studied had the desire for postpartum contraception which suggests an expected increased uptake if they are promptly referred to the family planning clinic after delivery. An integration of the family planning services with antenatal services will even improve the uptake. 
A study in Uganda showed that $28 \%$ of the women used modern contraceptive methods during the postpartum period.4 This is against $76.6 \%$ of our study women having the desire to practice postpartum contraception. However, the Ugandan study was the actual practice while ours was a desire and some of the women demonstrating the desire may not actually take up the contraception. Secondary educational attainment also had a significant association with the use of postpartum contraception in that study but this was not our finding. A similar study in Port Harcourt, Southsouth Nigeria showed $66.4 \%$ of the antenatal clients having willingness to practice contraception. ${ }^{5}$ This is similar to our own finding.

The index pregnancy being desired was found in our study to be significantly associated with the desire to practice contraception postpartum. This may be because these women probably have been planning their families (with contraceptives) with the result that a pregnancy comes only when it is desired. Furthermore, the finding in the study that previous use of contraception also has a significant association supports this thinking.

Parity also has a significant association with the desire for contraception. This probably is because of the simple reason that the larger the family size the more the woman would want to prevent more pregnancies. However, it would have been more informative also to know the number of living children and their gender.

Marital status is another significant association. Women who have partners and enjoy their support are known to have a higher contraception uptake. ${ }^{23}$

\section{CONCLUSION}

There was a high level of desire to practice postpartum contraception among antenatal clinic attendees at Awka. Parity, marital status, desired index pregnancy and previous practice of contraception all influence this desire.

\section{ACKNOWLEDGMENTS}

I wish to express my profound gratitude to Drs. M. Affusim, S. Nzeukwu and I. Aniedu who the registrars in the Department of Obstetrics and Gynaecology that did the data collection.

\section{Funding: No funding sources}

Conflict of interest: None declared

Ethical approval: The study was approved by the Institutional Ethics Committee

\section{REFERENCES}

1. Naanyu V, Baliddawa J, Peca E, Karfakis J, Nyagoha N, Koech B. An examination of postpartum family planning in western Kenya: "I want to use contraception but I have not been told how to do so". Afr J Reprod Health 2013;17(3):44-53.

2. Anzaku AS, Mikah S. Postpartum Resumption of Sexual Activity, Sexual Morbidity and Use of Modern Contraceptives among Nigerian Women in Jos Ann Med Health Sci Res. 2014;4(2):210-6.

3. World Health Organization. Programming strategies for postpartum family planning. Geneva: WHO; 2013. Available at http://www.who.int/reproductivehealth/publications/f amily_planning/ppfp_strategies/en/

4. Rutaremwa G, Kabagenyi A, Wandera SO, Jhamba T, Akiror E, Nviiri HL. Predictors of modern contraceptive use during the postpartum period among women in Uganda: a population-based crosssectional study. BMC Public Health.2015;15(1):262.

5. Allagoa DO, Nyengidiki TK. Knowledge, Attitude And Practice Of Contraception Amongst Antenatal Patients At The University Of Port Harcourt Teaching Hospital, Port Harcourt. Nig Health J. 2011;11(3):89-92.

6. Olatunji AD, Abudu, OO. A review of maternal mortality in LUTH. Nig Med Pract.1996;31(2):2-6.

7. Ogedengbe OK, Giwa OF, Adeboye M, Lisi CA. The acceptability and role of norplant as a long acting contraceptive in Lagos, Nig Trop J Obstet Gynaecol.1997;14(1):28-32.

8. Uzoigwe SA, John CT. Maternal mortality in the University of Port Harcourt Teaching Hospital, Port Harcourt in the last year before the new millennium. Niger J Med. 2004;13(1):32-4.

9. Adetoro OO. Maternal mortality. A 12-year survey at UITH, Ilorin, Nigeria. Int J Obstet Gynaecol, 1987. 25(2):93-8.

10. Ezebialu IU, Eke AC. Resumption of vaginal intercourse in the early postpartum period: Determinants and consideration for child spacing in a Nigerian population. J Obstet Gynecol. 2012;32(4):353-6.

11. Asekun-Olarimoye EO, Adebimpe WO, Bamidele JO, Odu OO, Asekun-Olarimoye IO, Ojofeitimi EO. Barriers to use of modern contraceptives among women in an inner-city area of Osogbo metropolis, Osun state, Nigeria. Int J Women's Health. 2013; 5:647-55.

12. Adanikin AI, Onwudegwu U, Loto OM. Influence of multiple antenatal counselling on modern contraceptive uptake in Nigeria. Eur. J. Contracept. Reproductive Health Care; 2013;18(5):381-7.

13. Avidime S, Aku-Akai L, Mohammed AZ, Adaji S, Shitu O, Ejembi C. Fertility Intentions, Contraceptive Awareness and Contraceptive Use among Women in Three Communities in Northern Nigeria. Afr J Reprod Health. 2010;14(3):65-70.

14. Igwegbe AO, Ugboaja JO, Monago EN. Prevalence and determinants of unmet need for family planning in Nnewi, south-east Nigeria Int $\mathbf{J}$ Med Med Sci 2009; 1(8):325-9. 
15. Akani CI, Enyinda CE, Babatunde S. Emergency contraception: Knowledge and perception of female undergraduates in the Niger Delta of Nigeria. Ghana Med J. 2008;42(2):68-70.

16. Okunade KS, Daramola E, Ajepe A, Sekumade A. A 3-year review of the pattern of contraceptive use among women attending the family planning clinic of a University Teaching Hospital in Lagos, Nigeria. Afr J Med Health Sci. 2016;15(2):69-73.

17. Idowu A, Aremu OA, Fehitola FO, Popoola GO. Knowledge, attitude and practice of contraception by female junior secondary school students in an urban community of Oyo-state, South west, Nigeria. Int J Reprod Contracept Obstet Gynecol 2017;6(11):475965.

18. Mandara M. Family planning in Nigeria and prospects for the future. Int J Gynecol Obstet. 2012; 117(1):1-4.

19. Omo-Aghoja LO, Omo-Aghoja VW, Aahoja CO, Okonofua FE, Aghedo O, Umueri C et al. Factors associated with the knowledge, practice and perceptions of contraception in rural southern Nigeria Ghana Med J. 2009; 43(3):115-21.
20. Gaikwad RA, Gadappa SN, Deshpande SS. Awareness of contraception in post-partum women in a tertiary care centre. Int $\mathbf{J}$ Reprod Contracept Obstet Gynecol. 2017;6(9):3850-4.

21. Olamijulo JA, Olamijulo JA, Olorunfemi G. Knowledge and Practice of Contraception among Pregnant Women Attending Antenatal Clinic at Lagos University Teaching Hospital. Niger J Med. 2012; 21(4):387-93.

22. Araoye MO. Research methodology with statistics for health and social sciences. $2^{\text {nd }}$ ed. Illorin: Nathadex Publications; 2008. 115-22.

23. Prata N, Bell S, Fraser A, Carvalho A, Neves I, Nieto-Andrade B. Partner support for family planning and modern contraceptive use in Luanda, Angola Afr J Reprod Health. 2017;21(2):35-48.

Cite this article as: Ezenyeaku CC, Ezebialu IU, Umeobika JC, Ikeako LC, Ubboe GI, Ojiyi CE, et al. Desire to practice postpartum contraception among antenatal women at Awka, Southeast Nigeria. Int J Reprod Contracept Obstet Gynecol 2018;7:1682-6. 